\title{
Effect of reduced dietary fat on estradiol, adiponectin, and IGF-I levels in postmenopausal women with breast cancer
}

This article was published in the following Dove Press journal:

Breast Cancer - Targets and Therapy

23 May 2017

Number of times this article has been viewed

\author{
Blanca Murillo-Ortiz' \\ Sandra Martínez-Garza' \\ Vanessa Cárdenas \\ Landeros' \\ Gerardo Cano Velázquez' \\ David Suárez García ${ }^{2}$ \\ 'Clinical Epidemiology Research \\ Unit, ${ }^{2}$ Department of Oncology, \\ Mexican Institute of Social Security, \\ Leon, Mexico
}

\begin{abstract}
Introduction: In recent years, epidemiological studies have strongly related obesity with an increased risk of developing postmenopausal breast cancer. The aromatization of fatty tissue increases the levels of estradiol and adiponectin, which is correlated with the body mass index (BMI). It is of interest to investigate the effect of reducing BMI on estradiol, adiponectin, and IGF-1, as reducing BMI could be a new strategy to limit the risk of recurrence during the adjuvant treatment of breast cancer.
\end{abstract}

Objective: The aim of this study is to investigate the effect of reduced dietary fat on the levels of serum estradiol, adiponectin, and IGF-1 among postmenopausal Mexican women with breast cancer.

Methods: In this controlled clinical trial, 100 female patients were randomly divided into two groups and followed for six months. Group $1(\mathrm{n}=50)$ was subjected to reduced dietary fat, whereas Group $2(n=50)$ was subjected to a control diet. The levels of serum estradiol and testosterone were determined using an enzyme-linked immunosorbent assay, whereas the concentrations of adiponectin and IGF-1 were determined using a radioimmunoassay.

Results: The patients subjected to reduced dietary fat showed a significant difference in BMI $(27.93 \pm 4.45$ vs $26.05 \pm 2.65 ; p=0.01)$ and waist circumference $(99.92$ vs $91.59 \mathrm{~cm}$; $p=0.0001)$ after the treatment. Moreover, a significant decrease in serum estradiol was observed $(21.23 \pm 14.32 \mathrm{vs} 16.05 \pm 10.25 \mathrm{ng} / \mathrm{mL} ; p<0.001)$. The adiponectin concentration also decreased significantly ( $47.53 \pm 12.19$ vs $42.52 \pm 12.34 \mu \mathrm{g} / \mathrm{mL} ; p=0.004)$, while IGF-1 and testosterone did not show significant changes $(p>0.05)$. In addition, BMI had a relationship with serum adiponectin $(r=-0.27 ; p=0.02)$ and estradiol $(r=0.37 ; p=0.001)$.

Conclusion: The current study shows that reducing BMI decreases serum estradiol and adiponectin. Large clinical trials are needed to investigate the role of adiponectin in breast cancer development in obese women.

Keywords: reduced dietary fat, breast cancer, hormone levels

\section{Introduction}

Breast cancer is the second highest cause of cancer-related death, and breast cancer mortality has increased in the recent years. Current research indicates that body composition increases the risk of recurrence and decreases survival. Nutritional status diagnosis plays an important role during breast cancer treatment, and diet is considered important as the prognosis and progression of breast cancer are strongly influenced by the dietary intake and nutritional status. ${ }^{1}$

An increase in body mass index (BMI) is associated with a higher-grade breast cancer and luminal B breast cancer, mainly in postmenopausal women. ${ }^{2}$ Obesity is
Correspondence: Blanca Murillo-Ortiz Clinical Epidemiology Research Unit, Mexican Institute of Social Security, UMAE No. I Bajio, B. López Mateos Esq. Insurgentes $\mathrm{S} / \mathrm{N}$, Colonia Los Paraísos, 37320 Leon, Guanajuato, Mexico Tel/fax +52477 7183039

Email bomo907@hotmail.com 
associated with an increased mortality among women with hormonal receptor (HR)-positive breast cancer, which may be a result of increased steroid hormone levels. ${ }^{3}$ Moreover, obesity contributes to a higher aromatization of body fat, which increases the levels of circulating hormones.

Besides being a target for circulating estrogens, the adipose tissue itself is a source of estrogen production through the aromatization of androgens. Furthermore, there is a direct relationship between body weight and aromatase activity. ${ }^{4}$

Sexual hormone synthesis and bioavailability are influenced by obesity. Estrogens are produced by aromatase in fatty tissue, from androgenic precursors produced in the adrenal and gonadal glands. An increased production of free fatty acids, adipokines, tumor necrosis factor alpha (TNF- $\alpha$ ), and resistin is observed in patients with a higher central fatty tissue, while adiponectin levels are low. Resistance to insulin leads to hyperinsulinemia because adiponectin sensitizes the tissues to the action of insulin, while TNF- $\alpha$ and resistin are counterregulatory. The production of IGF-1-binding protein in the liver is decreased by hyperinsulinemia, resulting in higher levels of free IGF-1, and insulin stimulates cell proliferation and halts apoptosis..$^{5-7}$

Thus, combining nutritional therapy and hormone therapy for breast cancer may help to reduce the levels of circulating estradiol to avoid its proliferative effect on cells and reduce the risk of metastasis. Adjuvant therapy using aromatase inhibitors will be less effective in the presence of obesity, which implies the necessity of multidisciplinary treatment, including nutritional evaluation, changes in diet, and a nutritional regime to reduce body fat.

$\mathrm{BMI}$ is an independent risk factor in patients with breast cancer, associated more with the triple-negative subtype of breast cancer among premenopausal patients; however, this association is not found in postmenopausal patients. ${ }^{8}$

The current study may provide important information to clarify the effect of diet on serum hormone levels which can be used as a treatment to decrease body fat, the role of body fat in breast cancer prognosis, and the proliferative effect of estradiol in malignant cells.

In the present study, the effect of reduced dietary fat on the levels of serum hormones in postmenopausal Mexican women with breast cancer was investigated, along with an analysis of the associated risk factors including BMI and other lifestyle factors.

\section{Patients and methods}

A prospective controlled study was carried out in a total of 100 postmenopausal women diagnosed with breast cancer at the Department of Oncology of the High Specialty Medical Unit No. 1 Bajio (IMSS), Leon, Guanajuato, Mexico. Patients were older than 48 years; their last menses was at least 1 year prior to the study, and previously, their menstrual cycles had been regular. Patients had been diagnosed with cancer at least a year before, had finished their chemotherapy treatment, and were undergoing adjuvant therapy using tamoxifen. The study was performed in accordance with the Declaration of Helsinki of the World Medical Association and was approved by the local Bioethics Committee of the High Specialty Medical Unit No. 1 Bajio (IMSS) (No. R 2008-1001-67). All patients signed an informed consent form for this investigation.

The participants were divided randomly into two groups: Group $1(\mathrm{n}=50)$ were subjected to reduced dietary fat and Group $2(n=50)$ were subjected to a control diet. A nutritional evaluation was performed according to the dietary, anthropometric, and biochemical indicators before and after six months of the diet treatment, which was designed in accordance with the initial evaluation for each patient. Patients were evaluated for their nutritional status during the 6-month follow-up period, with an appointment each month to verify adherence to the treatment.

\section{Diets}

Five meal menus per day were given to all patients with written instructions informing them of sanitary considerations and reheating methods.

\section{Group I: reduced dietary fat}

The proportions of each alimentary group were as follows: $12 \%$ fat, $68 \%$ carbohydrates, and $20 \%$ protein.

\section{Group 2: control diet}

The proportions for this regime were as follows: 50\% carbohydrates, $30 \%$ fat, and $20 \%$ protein. These were taken from the balanced diet recommendations of the American Dietetic Association.

\section{Blood serum analysis}

Venous blood samples were collected between 8:30 and 10:30 am, after 8-10 h of fasting. Samples were collected in vacuum tubes free of anticoagulant. Serum samples were stored at $-80^{\circ} \mathrm{C}$ until use. The levels of estradiol, adiponectin, and IGF-1 were determined using an enzyme-linked immunosorbent assay (ELISA).

Adiponectin levels were measured using a human adiponectin ELISA Kit (Linconplex kit, EzHADP-61 K), and IGF-1 levels were assessed using a Human IGF-I Quantikine 
ELISA Kit, with intra- and inter-assay coefficients of variability of $<7 \%$ and $<10 \%$, respectively.

\section{Statistical analysis}

All data are presented as mean \pm standard error of the mean, and $p<0.05$ was considered to indicate statistical significance.

The groups were compared using a two-tailed $t$-test and the Kruskal-Wallis test. A multiple regression model was used to analyze the baseline BMI, age, and tumor grade.

Correlations were measured using Pearson's test to assess the association between serum levels of estradiol and adiponectin, and BMI. The analysis was carried out using Medcall 13.1.

\section{Results}

The mean age of Group 1 and Group 2 was $50.45 \pm 7.94$ and $52.26 \pm 6.11$ years, respectively $(p>0.05)$.

In Group 1, breast cancer of clinical stages 2 (46\%) and 3 (54\%) was most frequent. The most common histological diagnosis was ductal carcinoma (58\%), followed by lobular carcinoma (22\%) and others (20\%). The clinical and anthropometric characteristics of the patients are shown in Table 1.

\section{Anthropometric parameters}

In Group 1, BMI was significantly different before and after treatment $\left(27.93 \pm 4.45 \mathrm{vs} 26.05 \pm 2.65 \mathrm{~kg} / \mathrm{m}^{2} ; p=0.01\right)$, and waist circumference was significantly reduced $(99.92 \pm 11.05$ vs $91.59 \pm 9.59 \mathrm{~cm} ; p=0.0001)$.

Moreover, the difference in the final BMI between the groups was significant $(p=0.04)$, unlike the muscle mass percentage at the end of the treatment $(p=0.29)$.

\section{Serum levels of estradiol, adiponectin, and IGF-I}

In Group 1, estradiol levels had significantly decreased $(21.23 \pm 14.32$ vs $16.05 \pm 10.25 \mathrm{ng} / \mathrm{mL} ; p=0.003)$ and adiponectin levels were significantly lower following treatment ( $47.53 \pm 12.19$ vs $42.52 \pm 12.34 \mu \mathrm{g} / \mathrm{mL} ; p=0.004)$. Glucose levels were also decreased $(96.71 \pm 4.94$ vs $89.56 \pm 9.91 \mathrm{mg} / \mathrm{dL} ; p=0.0001)$.

However, no statistically significant difference in the levels of IGF-1 (69.29 \pm 39.91 vs $63.57 \pm 35.77 \mathrm{UI} ; p=0.20)$ was found following treatment in Group 1. BMI was correlated with serum levels of adiponectin $(r=-0.27 ; p=0.02)$, and a direct correlation with estradiol levels $(r=0.37 ; p=0.001)$ was observed in all the patients.

In Group 2, there was no difference in the levels of estradiol, adiponectin, and IGF-1 following treatment $(p>0.05$; Table 2).

A multiple regression model in Group 1 did not show a significant association of baseline BMI, age, and tumor grade with pre- and post-intervention values of IGF 1 and adiponectin $(p>0.05)$.

Table I Differences between anthropometric and clinical parameters in breast cancer diagnosed women with reduced dietary fat (Group I) and dietary recommendations (Group 2)

\begin{tabular}{|c|c|c|c|c|c|}
\hline Clinical parameter & Group I initial & Group I final & Group 2 initial & Group 2 final & $\mathbf{p}$ \\
\hline Age (years) & $50.45 \pm 7.94$ & & $52.26 \pm 6.11$ & & $>0.05$ \\
\hline \multirow[t]{2}{*}{ BMI $\left(\mathrm{kg} / \mathrm{m}^{2}\right)$} & $27.93 \pm 4.45$ & $26.05 \pm 2.65^{*}$ & $28.83 \pm 4.60$ & $28.74 \pm 3.10^{* *}$ & $0.01 *$ \\
\hline & & & & & $0.90 * *$ \\
\hline Overweight: $25-26.9 \mathrm{~kg} / \mathrm{m}^{2}$ & $8(15.3 \%)$ & I I (23.0\%) & & & \\
\hline Obesity grade I: $27-29.9 \mathrm{~kg} / \mathrm{m}^{2}$ & $31(61.5 \%)$ & $31(61.5 \%)$ & & & \\
\hline Obesity grade $2: 30-39.9 \mathrm{~kg} / \mathrm{m}^{2}$ & II (23.0\%) & $8(15.3 \%)$ & & & \\
\hline \multirow[t]{2}{*}{ Waist circumference $(\mathrm{cm})$} & $99.92 \pm 11.05$ & $91.59 \pm 9.59 *$ & $95.03 \pm 10.73$ & $94.00 \pm 9.89 * *$ & $* 0.0001$ \\
\hline & & & & & $* * 0.61$ \\
\hline \multicolumn{6}{|l|}{ Clinical stage, n (\%) } \\
\hline II & $23(46 \%)$ & & $26(52 \%)$ & & \\
\hline III & $27(54 \%)$ & & $24(48 \%)$ & & \\
\hline \multicolumn{6}{|l|}{ Histologic type, n (\%) } \\
\hline Ductal & $27(54 \%)$ & & $30(60.00 \%)$ & & \\
\hline Lobar & $13(26 \%)$ & & $15(31.00 \%)$ & & \\
\hline Others & $10(20 \%)$ & & $5(9.00 \%)$ & & \\
\hline \multicolumn{6}{|l|}{ Hormonal receptors positive } \\
\hline Estrogen & $99 \%$ & & $99 \%$ & & \\
\hline Progesterone & $98 \%$ & & $98 \%$ & & \\
\hline
\end{tabular}

Note: *Initial vs final Group I; **initial vs final Group 2.

Abbreviation: BMI, body mass index. 
Table 2 Effects of reduced dietary fat (Group I) on adiponectin, estradiol, and IGF-I in serum

\begin{tabular}{llll}
\hline Metabolic profile & Group I initial & Group I final & $\boldsymbol{p}$ \\
\hline Estradiol $(\mathrm{ng} / \mathrm{mL})$ & $21.23 \pm 14.32$ & $16.05 \pm 10.25$ & 0.003 \\
Testosterone $(\mathrm{ng} / \mathrm{mL})$ & $0.23 \pm 0.14$ & $0.19 \pm 0.17$ & 0.07 \\
Adiponectin $(\mu \mathrm{g} / \mathrm{mL})$ & $47.53 \pm 12.19$ & $42.52 \pm 12.34$ & 0.004 \\
IGF-I $(\mathrm{UI})$ & $69.29 \pm 39.91$ & $63.57 \pm 35.77$ & 0.45 \\
Glucose $(\mathrm{mg} / \mathrm{dL})$ & $96.71 \pm 4.94$ & $89.56 \pm 9.91$ & 0.000 I \\
\hline
\end{tabular}

\section{Discussion}

The current study shows the effects of reduced dietary fat on the levels of circulating estradiol and adiponectin in postmenopausal patients diagnosed with breast cancer. In recent studies, low adiponectin levels have been shown to be associated with the development of different types of cancer, and this association is more significant in patients with obesity. The most aggressive phenotype has been shown to be associated with the expression of the IGF-1 receptor, and serum IGF-1 concentrations have also been reported as an important factor., ${ }^{9,10}$

The increased risk of developing HR-positive breast cancer in obese postmenopausal women has been attributed, in part, to increased levels of circulating estradiol, which is related to both increased adipose tissue and elevated aromatase expression in subcutaneous adipose tissue. ${ }^{11-13}$ The current study found that estrogen levels in patients who followed diet with reduced fat for 6 months decreased significantly, as did their BMI. Thus, strategies to reduce the levels of circulating estradiol may serve as a maintenance therapy in patients with HR-positive breast cancer (using tamoxifen and aromatase inhibitors). However, there is no previous investigation on whether it is possible to reduce the levels of estradiol using nutritional treatment.

Obesity is prevalent in the majority of patients with breast cancer; in the current study, $74 \%$ of the patients were obese and $16 \%$ were overweight. Furthermore, the breast cancer stage was grade 1 in $61 \%$ and grade 2 in $23 \%$ of patients. In addition to the impact on the risk of breast cancer, obesity has been recognized as a poor prognostic factor among breast cancer survivors. ${ }^{14-20}$

Adiponectin had been studied in patients with type 2 diabetes mellitus and obesity, and it was demonstrated that it is inversely correlated with adiposity level. ${ }^{21}$ It is strongly involved in cancer development but some researchers still consider its action to be inconsistent or context-specific. Some experimental studies report an antiproliferative effect of adiponectin on breast cancer cells that do not express the estrogen receptor; ${ }^{22,23}$ however, this effect was not observed in estrogen receptor-positive cells. ${ }^{24-29}$
Elevated levels of serum adiponectin, ranging from 27 to $63 \mu \mathrm{g} / \mathrm{mL}$, were found prior to treatment and after six months of following a low-fat diet, and adiponectin levels decreased significantly, as did estradiol levels. Meta-analyses and prospective cohort studies have consistently found that the reduced risk of breast cancer and regular soy food intake ${ }^{30}$ are related to lower circulating levels of some inflammatory markers implicated in breast cancer risk. Nadudara et al found no statistically significant difference in the levels of these adipocytokines with a very low-fat diet or soy supplementation. However, they reported differences in TNF-a levels between the very low-fat and control diet. ${ }^{30}$

Cross-sectional studies, which were conducted mostly in Western populations, ${ }^{31}$ and often among men with diabetes, cardiovascular disease, or other conditions, ${ }^{32-34}$ suggest that the intake of alcohol and coffee and diets rich in cereal fiber may significantly affect serum adiponectin levels. Wintrob et $\mathrm{al}^{35}$ demonstrated that in patients with type 2 diabetes mellitus who developed breast cancer, adiponectin levels were lower than in patients with breast cancer without type 2 diabetes mellitus. In the current study, there were no patients with type 2 diabetes mellitus; however, serum glucose levels were significantly reduced following the low-fat treatment.

The current results suggest a possible relationship between estradiol and adiponectin levels, and the role of adiponectin in the expression of a particular type of estrogen receptor, because the effect of estrogen has been shown to be dependent on the status of the estrogen receptor alpha. This could suggest a correlation between adiponectin and estradiol serum levels in breast cancer. ${ }^{36,37}$

Recently, cross-talk between IGF-1 and adiponectin has been found to be associated with breast cancer. ${ }^{38}$ Mauro et al demonstrated that low levels of adiponectin induce cellular growth independently of IGF-1 in estrogen receptor alphapositive breast cancer cells. This study found no statistically significant differences in the levels of IGF-1 after treatment, although estradiol and adiponectin levels decreased significantly after six months of reduced dietary fat in patients with estrogen receptor alpha positive breast cancer.

Moreover, Mauro et al demonstrated the role of adiponectin in several types of breast cancer. In cells that are estrogen receptor negative, the study showed that adiponectin has an antagonist effect on growth stimulation produced by IGF-1, which halts cell migration. However, in estrogen receptor-positive breast cancer cells, adiponectin produces a proliferative effect that has synergy with IGF-1 expression. ${ }^{38}$

Miyoshi et al first highlighted the relationship between hypoadiponectinemia and increased risk of breast cancer. ${ }^{39}$ 
A recent meta-analysis of eight observational studies found that low adiponectin levels are associated with an increased risk of breast cancer in postmenopausal but not premenopausal women. ${ }^{40}$ The current study indicates that adiponectin concentration was decreased after weight loss, and these changes might have occurred through both mechanisms of hormonal therapy and body composition changes. However, some studies have produced inconsistent and confusing results, and this may be explained by the presence of different isoforms of adiponectin. ${ }^{41}$ Katira et al reported that normal serum adiponectin levels were noted in stage I and II breast cancer, and its levels decreased with disease progression. ${ }^{42}$ Hence, further investigation of the role of different forms of adiponectin in breast cancer risk is needed.

The current results fit well with recent findings demonstrating that adiponectin should be applied as a new therapeutic strategy for the treatment of breast cancer and also to prevent the risk conferred by obesity in the development of breast cancer.

\section{Conclusion}

The current study demonstrates that reduced dietary fat may regulate estradiol and adiponectin levels. Monitoring BMI and the proportion of fatty tissue is essential during adjuvant therapy. Adiponectin may be a new biomarker to evaluate the risk for the development of breast cancer in obese women. Large clinical trials are needed to validate these findings.

\section{Disclosure}

The authors report no conflicts of interest in this work.

\section{References}

1. Mohammadi S, Sulaiman S, Koon PB, Amani R, Hosseini SM. Association of nutritional status with quality of life in breast cancer survivors. Asian Pac. J Cancer Prev. 2013;14(12):7749-7755.

2. Santa-Maria CA, Zhao YD, Ketring N, Rodriguez I, Condren A, Euhus D. Relationship of body mass index to the intrinsic subtypes of breast cancer. J Clin Oncol. 2011;29(15 Suppl):1529.

3. Kawai M, Minami Y, Nishino Y, Fukamachi K, Ohuchi N, Kakugawa Y. Body mass index and survival after breast cancer diagnosis in Japanese women. BMC Cancer. 2012;12:149.

4. Mattsson C, Olsson T. Estrogens and glucocorticoid hormones in adipose tissue metabolism. Curr Med Chem. 2007;14(27):2918-2924.

5. Carmichael AR. Obesity as a risk factor for development and poor prognosis of breast cancer. BJOG. 2006;113:1160-1166.

6. Carmichael AR, Bates T. Obesity and breast cancer: a review of the literature. Breast. 2004;13:85-92.

7. Calle EE, Kaaks R. Overweight, obesity and cancer: epidemiological evidence and proposed mechanisms. Nat Rev Cancer. 2004;4:579-591.

8. Sahin S, Erdem GU, Karatas F, et al. The association between body mass index and immunohistochemical subtypes in breast cancer. Breast. 2016;32:227-236.

9. LeRoith D, Roberts CT Jr. The insulin-like growth factor system and cancer. Cancer Lett. 2003;195:127-137.
10. Mauro L, Pellegrino M, De Amicis F, et al. Evidences that estrogen receptor $\alpha$ interferes with adiponectin effects on breast cancer cell growth. Cell Cycle. 2014;13:553-564.

11. James FR, Wootton S, Jackson A, Wiseman M, Copson ER, Cutress RI. Obesity in breast cancer - what is the risk factor? Eur J Cancer. 2015;51(6):705-720.

12. Catalano S, Mauro L, Marsico S, et al. Leptin induces, via ERK1/ERK2 signal, functional activation of estrogen receptor alpha in MCF-7 cells. J Biol Chem. 2004;279:19908-19915.

13. Kadowaki T, Yamauchi T. Adiponectin and adiponectin receptors. Endocr Rev. 2005;26:439-451.

14. Morris PG, Hudis CA, Giri D, et al. Inflammation and increased aromatase expression occur in the breast tissue of obese women with breast cancer. Cancer Prev Res (Phila). 2011;4:1021-1029.

15. Whiteman MK, Hillis SD, Curtis KM, McDonald JA, Wingo PA, Marchbanks PA. Body mass and mortality after breast cancer diagnosis. Cancer Epidemiol Biomarkers Prev. 2005;14:2009-2014.

16. Majed B, Moreau T, Senouci K, Salmon RJ, Fourquet A, Asselain B. Is obesity an independent prognosis factor in woman breast cancer? Breast Cancer Res Treat. 2008;111:329-342.

17. Petrelli JM, Calle EE, Rodriguez C, Thun MJ. Body mass index, height, and postmenopausal breast cancer mortality in a prospective cohort of US women. Cancer Causes Control. 2002;13:325-332.

18. Ewertz M, Jensen MB, Gunnarsdottir KA, et al. Effect of obesity on prognosis after early-stage breast cancer. J Clin Oncol. 2011; 29:25-31.

19. Rose DP, Vona-Davis L. Influence of obesity on breast cancer receptor status and prognosis. Expert Rev Anticancer Ther. 2009;9:1091-1101.

20. Protani M, Coory M, Martin JH. Effect of obesity on survival of women with breast cancer: systematic review and meta-analysis. Breast Cancer Res Treat. 2010;123:627-635.

21. Weyer C, Funahashi T, Tanaka S, et al. Hypoadiponectinemia in obesity and type 2 diabetes: close association with insulin resistance and hyperinsulinemia. J Clin Endocrinol Metab. 2001;86(5):1930-1935.

22. Kang JH, Lee YY, Yu BY, et al. Adiponectin induces growth arrest and apoptosis of MDA-MB-231 breast cancer cell. Arch Pharm Res. 2005;28:1263-1269.

23. Dos Santos E, Benaitreau D, Dieudonne MN, et al. Adiponectin mediates an antiproliferative response in human MDA-MB 231 breast cancer cells. Oncol Rep. 2008;20:971-977.

24. Körner A, Pazaitou-Panayiotou K, Kelesidis T, et al. Total and highmolecular-weight adiponectin in breast cancer: in vitro and in vivo studies. J Clin Endocrinol Metab. 2007;92:1041-1048.

25. Dieudonne MN, Bussiere M, Dos Santos E, Leneveu MC, Giudicelli Y, Pecquery R. Adiponectin mediates antiproliferative and apoptotic responses in human MCF7 breast cancer cells. Biochem Biophys Res Commun. 2006;345:271-279.

26. Jardé T, Caldefie-Chézet F, Goncalves-Mendes N, et al. Involvement of adiponectin and leptin in breast cancer: clinical and in vitro studies. Endocr Relat Cancer. 2009;16:1197-1210.

27. Treeck O, Lattrich C, Juhasz-Boess I, Buchholz S, Pfeiler G, Ortmann $\mathrm{O}$. Adiponectin differentially affects gene expression in human mammary epithelial and breast cancer cells. Br J Cancer. 2008;99: 1246-1250.

28. Pfeiler GH, Buechler C, Neumeier M, et al. Adiponectin effects on human breast cancer cells are dependent on 17-beta estradiol. Oncol Rep. 2008;19:787-793.

29. Landskroner-Eiger S, Qian B, Muise ES, et al. Proangiogenic contribution of adiponectin toward mammary tumor growth in vivo. Clin Cancer Res. 2009; 15:3265-3276.

30. Nadadura M, Stanczykb FZ, Tseng CC, Kima L, Wu AH. The effect of reduced dietary fat and soy supplementation on circulating adipocytokines in postmenopausal women: a randomized controlled 2-month trial. Nutr Cancer. 2016;68(4):554-559.

31. Wu AH, Yu MC, Stanczyk FZ, Tseng CC, Pike MC. Anthropometric, dietary, and hormonal correlates of serum adiponectin in Asian American women. Nutr Cancer. 2011;63(4):549-557. 
32. Qi L, Rimm E, Liu S, Rifai N, Hu FB. Dietary glycemic index, glycemic load, cereal fiber, and plasma adiponectin concentration in diabetic men. Diabetes Care. 2005;28:1022-1028.

33. Mantzoros CS, Williams CJ, Manson JE, Meigs JB, Hu FB. Adherence to the Mediterranean dietary pattern is positively associated with plasma adiponectin concentrations in diabetic women. Am J Clin Nutr. 2006;84:328-335.

34. Miyazaki T, Shimada K, Mokuno H, Daida H. Adipocyte derived plasma protein, adiponectin, is associated with smoking status in patients with coronary artery disease. Heart. 2003;89:663.

35. Wintrob ZA, Hammel JP, Khoury T, et al. Insulin use, adipokine profiles and breast cancer prognosis. Cytokine. 2017;89:45-61.

36. Kakugawa Y, Tada H, Kawai M, et al. Associations of obesity and physical activity with serum and intratumoral sex steroid hormone levels among postmenopausal women with breast cancer: analysis of paired serum and tumor tissue samples. Breast Cancer Res Treat. 2017;162(1):115-125.
37. Yamauchi T, Kamon J, Waki H, et al. The fat-derived hormone adiponectin reverses insulin resistance associated with both lipoatrophy and obesity. Nat Med. 2001;7:941-946.

38. Mauro L, Naimo GD, Ricchio E, Panno ML, Andò S. Cross-talk between adiponectin and IGF-IR in breast cancer. Front Oncol. 2015;5:157.

39. Miyoshi Y, Funahashi T, Kihara S, et al. Association of serum adiponectin levels with breast cancer risk. Clin Cancer Res. 2003;9: 5699-5704.

40. Ye J, Jia J, Dong S, et al. Circulating adiponectin levels and the risk of breast cancer: a meta-analysis. Eur J Cancer Prev. 2014;23:158-165.

41. Guo M-m, Duan X-n, Cui S-d, et al. Circulating high-molecular-weight (HMW) adiponectin level is related with breast cancer risk better than total adiponectin: a case-control study. PLoS One. 2015;10(6): e0129246.

42. Katira A, Tan PH. Evolving role of adiponectin in cancer-controversies and update. Cancer Biol Med. 2016;13(1):101-119.

\section{Publish your work in this journal}

Breast Cancer - Targets and Therapy is an international, peerreviewed open access journal focusing on breast cancer research, identification of therapeutic targets and the optimal use of preventative and integrated treatment interventions to achieve improved outcomes, enhanced survival and quality of life for the cancer patient.
The manuscript management system is completely online and includes a very quick and fair peer-review system, which is all easy to use. Visit http://www.dovepress.com/testimonials.php to read real quotes from published authors.

Submit your manuscript here: https://www.dovepress.com/breast-cancer---targets-and-therapy-journal 